INTERNATIONAL JOURNAL OF RESEARCHES IN BIOSCIENCES, AGRICULTURE AND TECHNOLOGY (c) VISHWASHANTI MULTIPURPOSE SOCIETY (Global Peace Multipurpose Socie ty) R. No. MH-659/13 (N)

\title{
SUSTAINABLE DEVELOPMENT OF RURAL AREA THOUGH ORGANIC FARMING
}

\author{
R. L. Deshmukh \\ De partment of Botany, PemrajSarda College, Ahme dnagar -414001. \\ rajendradeshmukhwai@gmail.com
}

\begin{abstract}
:
Organic farming is a me thod of cultivation which involves use of manures, crop rotation and minimum tillage. This form of agriculture meets the needs of present generation without endangering the resource base of future generations. Various steps in organic farming are watershed management, tillage, efficient water manage ment, weed management, pest management and crop rotation. Organic farming maintains clean environment and nutritious food without pesticide residues. It is an urgent need to train every farmer for organic farming to have sus tainable rural de ve lopment.
\end{abstract}

Keywords: Organic Farming, Sustainable, Rural Development.

\section{Introduction:}

Due to misuse of agrochemicals number of problems are created in agriculture viz. land degradation, pesticide residue in farm produce, soil, air and water pollution, To overcome these problems there is a need of sustainable agriculture to avoid rapid depletion and degradation of natural resources like soil, water etc.

Organic farming is a system of cultivation with the use of manures, crop rotation and minimum tillage. This from of farming meets the needs of the present generation without endangering the resource base of the future generations. Ecological balance is maintained through organic farming. Various Steps in organic farming are as follows.

\section{Methodology:}

1) Watershed management- It helps in conservation of soil and water. Conservation of soil and water is done by continuous contour trenches (C.C.T), afforestration, gully control, cement concrete check dams, Kolhapur technique wares (K.T. wares) etc, To maintain fertility of soil in the field for every field the re should be border of green manuring plants like Glyricidiasps,Sesbaniasps,

Moringa,

Pongamiapinnata, Bauhinia, racemosa, Bahuniavariegataetc.

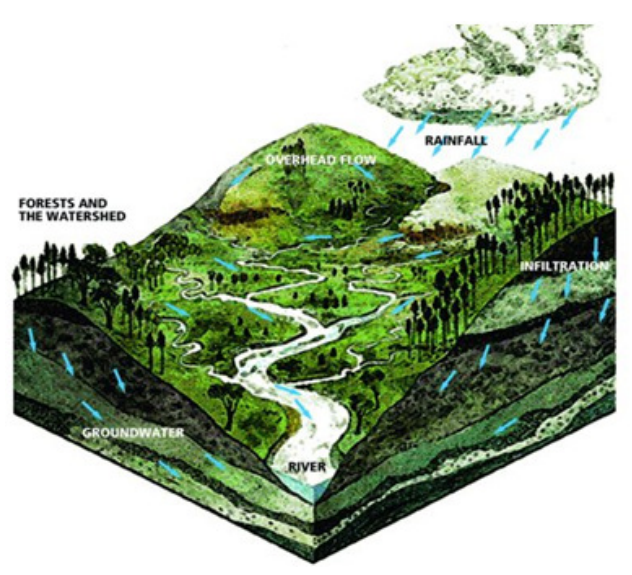

2) Tillage - Tillage is a well known soil and water conservation practice which makes soil surface more permeable to infilteration of rainwater into the soil. Tillage improves weed control. Tillage helps in timely decomposition of organic matter. Managing top $8 \mathrm{~cm}$ of soil is vital because most of the biological activity, microorganisms and organic matter is present at this depth.

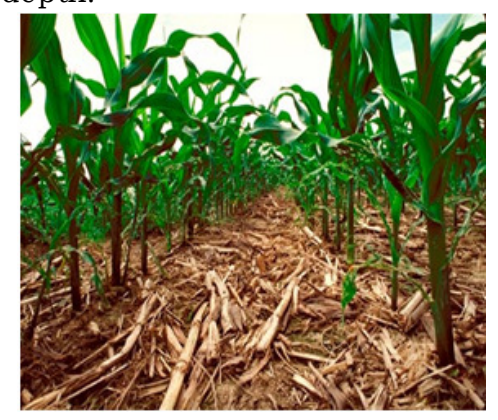

3) Nutrient Management - The principle of organic farming is feed soil to feed plants. In organic farming crop rotation is playing important role. Various biofertitizers are used to maintain fertility of the soil. These biofertilizers are Farm Yard Manure (F.Y.M.) ,Compost, Green 
manures, Azolla,B.G.A, Azotobacter, Rhizobium,Trichoderma,Phosphate Solubilizing. Bacteria (PSB), Gobar gas sludge, dung Slurry, concentrated organic manures like groundnut cakes, Vermicompost etc. Almost all parts of the crop plants after harvesting should be buried in the soil.

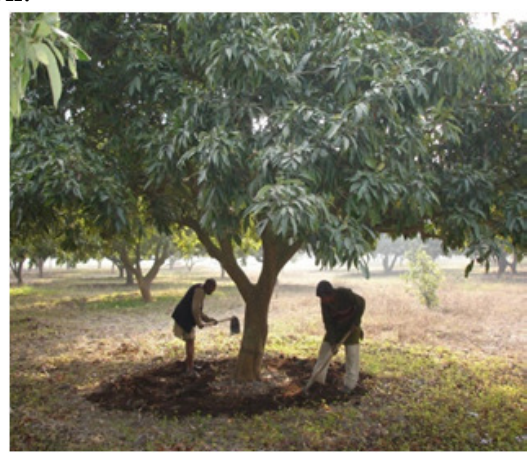

4) Efficient Water management :- It involves proper rainwater management as well as irrigation water management. Rainwater management involves water harvesting, supplemental irrigation and reduction of evapotranspiration. Irrigation water management involves irrigation at proper time with adequate quantity without water logging,salinity and alkalinity.

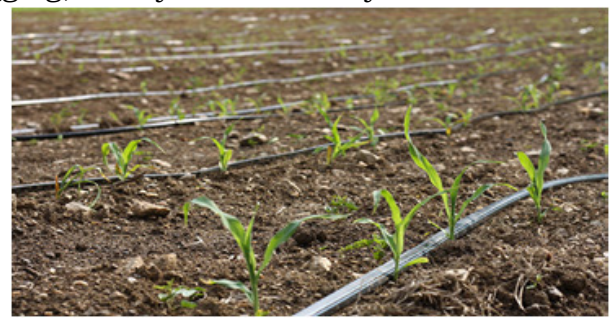

5) Weed management :- In weed management cultural, physical and biological methods of weed control are very important. Weeds are controlled by crop rotation, tillage and hand weeding. Weed population is tolerated at certain period of crop growth as they help in nutrient recycling, pest control, soil conservation and organic matter improvement. (Yellamanda et al, 2014)

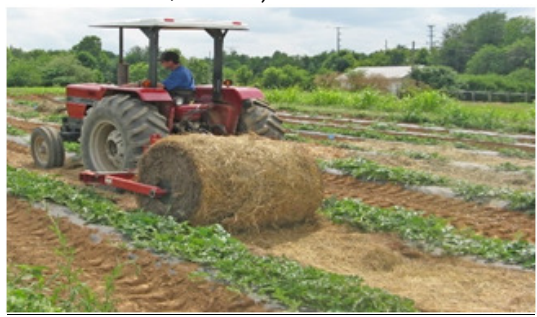

6) Pest management: - Farmers should use integrated pest control method. It involves cultural and biological methods, use of resistant varieties, neem, bacteria and fungi

(Trichodermasps.)

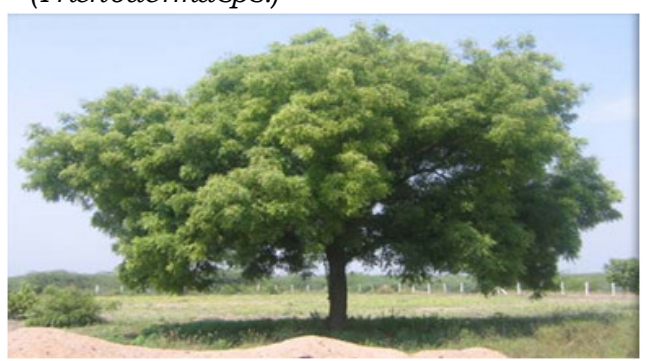

7) Crop rotation :- Farmers should grow leguminous crops and cereal crops alternately in the same field. If leguminous crop e.g. soybean is taken in kharif season it should be alternated with wheat or jowar in rabbi season. Crop rotation is very important for soil fertility manage ment, weed, insect and disease control.

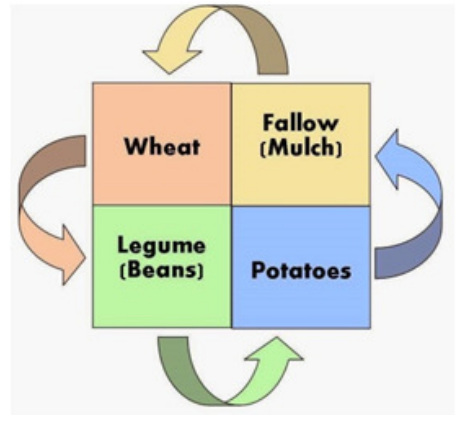

\section{Conclusion:}

Ecological balance is maintained through organic farming. There is low cost of cultivation. Organic farming maintains clean environment and nutritious food without pesticide residues. For good rural development farmers should attend various training programmes in agriculture universities. They should meet expert farmers and exchange ideas. They should hear programmes from radio, T.V. \& should read news papers like Agrowon.

\section{References:}

1. Dr. T. Yellamanda Reddy and Prof. G.H. SankaraReddi (2014) . Principles of Agronomy.

2. D.C.Das(2008)Manures and fertilizers.

3. MangalaRai (2006) Handbook of Agriculture, ICAR,

4. Dr. K.L.Chadha (2009)Handbook of Horticulture, ICAR, New Delhi. 